\title{
Hemodynamic effects of renin-angiotensin-aldosterone inhibitor and $\beta$-blocker combination therapy vs. $\beta$-blocker monotherapy for portal hypertension in cirrhosis: A meta-analysis
}

\author{
JIANRONG WANG ${ }^{1 *}$, WENXIA LU ${ }^{2 *}$, JINGJING LI ${ }^{3 *}$, RONG ZHANG ${ }^{2}$, \\ YUQING ZHOU ${ }^{4}$, QIN YIN $^{4}$, YUANYUAN ZHENG ${ }^{3}$, FAN WANG $^{3}$, YUJING XIA ${ }^{3}$, KAN CHEN $^{3}$, \\ SAINAN $\mathrm{LI}^{3}$, TONG LIU ${ }^{3}$, JIE LU ${ }^{3}$, YINGQUN ZHOU ${ }^{3}$ and CHUAN-YONG GUO ${ }^{3}$ \\ ${ }^{1}$ Department of Gastroenterology, Nanjing Jiangbei People's Hospital Affiliated to Nantong University, Nanjing, \\ Jiangsu 210048; ${ }^{2}$ The First Clinical Medical College of Nanjing Medical University, Nanjing, Jiangsu 210029; \\ ${ }^{3}$ Department of Gastroenterology, Shanghai Tenth People's Hospital, Tongji University School of Medicine, \\ Shanghai 200072; ${ }^{4}$ Department of Gastroenterology, Shanghai Tenth People's Hospital, \\ The First Affiliated Hospital of Soochow University, Suzhou, Jiangsu 215006, P.R. China
}

Received October 14, 2015; Accepted November 25, 2016

DOI: $10.3892 / \mathrm{etm} .2017 .4210$

\begin{abstract}
. $\beta$-blockers are commonly used for the treatment of acute variceal bleeding in cirrhosis. Renin-angiotensin-aldosterone antagonists (angiotensin I-converting enzyme inhibitors, angiotensin receptor blockers and aldosterone antagonists) are potential therapies for portal hypertension. Several studies have compared the renin-angiotensin-aldosterone system (RAAS) inhibitor and $\beta$-blocker combination therapy vs. $\beta$-blocker monotherapy, with inconsistent results. The aim of the present study was to assess the efficacy of the RAAS inhibitor and $\beta$-blocker combination therapy vs. $\beta$-blocker monotherapy for hepatic vein pressure gradient (HVPG) reduction in cirrhosis. Studies were obtained using PubMed, Embase, Medline and Cochrane library databases up to July 2015, and the weighted mean difference (WMD) in HVPG reduction was used as a measure of treatment efficacy. In total, three studies (91 patients) were included. When compared to the $\beta$-blocker monotherapy, the RAAS inhibitor and $\beta$-blocker combination therapy resulted in a significant HVPG reduction [WMD 1.70; 95\% confidence interval (CI): 0.52-2.88]. However, there was no significant difference in the heart rate reduction between
\end{abstract}

Correspondence to: Dr Chuan-Yong Guo or Dr Yingqun Zhou, Department of Gastroenterology, Shanghai Tenth People's Hospital, Tongji University School of Medicine, 301 Yanchang Road, Shanghai 200072, P.R. China

E-mail: guochuanyong@hotmail.com

E-mail: qzh02@163.com

*Contributed equally

Key words: angiotensin receptor blocker, aldosterone antagonist, angiotensin I-converting enzyme inhibitor, $\beta$-blockers, hepatic venous pressure gradient, portal hypertension the monotherapy and combination therapy groups (WMD -0.11 ; 95\% CI: -3.51-3.29). In addition, no significant difference in the hemodynamic response was observed between the two groups (WMD 1.46; 95\% CI: 0.93-2.30). In conclusion, the RAAS inhibitor and $\beta$-blocker combination therapy reduces portal hypertension significantly and to a greater extent than $\beta$-blocker monotherapy. Both therapies reduced the heart rate to similar levels; however, the RAAS inhibitor and $\beta$-blocker combination therapy reduced the mean arterial pressure to a greater extent. Due to the limited number of studies included, the data available do not allow a satisfactory comparison of adverse events. Moreover, further larger-scale trials are required in order to strengthen the results of the present study.

\section{Introduction}

Portal hypertension is an important cause of morbidity and mortality in cirrhotic patients, which can lead to severe complications, including esophageal variceal bleeding $(1,2)$, ascites, hepatic encephalopathy, hepatorenal syndrome, bacteremia and hypersplenism. To date, non-selective $\beta$-blockers (NSBBs) are the drugs of choice for the treatment of esophageal variceal bleeding in cirrhotic patients. However, it has been revealed that only $30-40 \%$ of the patients under long-term therapy with NSBBs demonstrate a good hemodynamic response (reduction in HVPG to $\leq 12 \mathrm{mmHg}$ or at least a $20 \%$ reduction from the baseline), and another $15 \%$ do not tolerate NSBBs (3). In the past few years, studies have revealed that the renin-angiotensin-aldosterone system (RAAS) is important in chronic hepatic diseases and portal hypertension. Angiotensin II was found to stimulate hepatic stellate cells in order to increase intrahepatic resistance and promote fibrosis (4). Moreover, in addition to its established effect of increasing portal vein blood flow via water-sodium retention (5), aldosterone has been shown to increase inflammation, endothelial dysfunction, oxidative stress and insulin resistance (6). In addition, a previous systematic review and meta-analysis confirmed that 
antagonists of the RAAS appear to be able to decrease HVPG in patients with compensated cirrhosis (7). Theoretically, as RAAS inhibitors and $\beta$-blockers function via different mechanisms to decrease the pressure of portal veins, it is possible that the RAAS inhibitor and $\beta$-blocker combination therapy may lead to a more significant reduction in portal venous pressure. Several studies (8-10) have previously compared the RAAS inhibitor and $\beta$-blocker combination therapy vs. $\beta$-blocker monotherapy. However, the results remain inconsistent.

The aim of the present study was to assess the efficacy of RAAS inhibitor and $\beta$-blocker combination therapy vs. $\beta$-blocker monotherapy on HVPG reduction in patients with cirrhosis.

\section{Materials and methods}

Inclusion and exclusion criteria. Studies were included using the following criteria: i) Full-text article; ii) randomized controlled trial; iii) cirrhosis; iv) clinically significant portal hypertension; v) if the study was a clinical trial comparing the effects of RAAS inhibitor and $\beta$-blocker combination therapy with $\beta$-blocker monotherapy on portal pressure; and vi) HVPG measurement before and after treatment. Moreover, studies were excluded if TIPS or a surgical shunt were present.

Search strategy. PubMed, Embase, Medline and the Cochrane Library were searched up to July 2015 to retrieve pertinent studies $(11,12)$. We searched (losartan OR candesartan OR irbesartan OR valsartan OR telmisartan OR olmesartan OR enalapril OR quinapril OR ramipril OR lisinopril OR captopril OR fosinopril OR perindopril OR RASS inhibitor OR ACEI OR ATII blocker OR angiotensin inhibitor OR renin angiotensin OR eplerenone OR spironolactone OR aldactone OR canrenone) AND (adrenergic $\beta$-antagonists OR $\beta$ blockers OR propranolol OR nadolol OR timolol) AND (portal hypertension OR cirrhosis) AND controlled trials. A manual search of the reference lists of related articles and reviews was also performed. Moreover, related congresses were hand-searched.

Data extraction. Two authors (Dr Jianrong Wang and Dr Wenxia Lu) extracted data independently. Discrepancies were resolved through discussion before the analyses. The following data were extracted from each trial: i) Trial characteristics such as study population demographics, intervention and control and time of outcome measured; ii) patient characteristics such as the number of patients, age, gender ratio, Child-Pugh class, number of patients with previous variceal hemorrhage and ascites; iii) outcome such as the reduction in HVPG, number of patients achieving a hemodynamic response, change in heart rate and mean arterial pressure (MAP) as adverse events.

Methodological quality assessment. Methodological quality of the articles included was assessed using the Jadad scale and Schulz hidden grouping $(13,14)$. A Jadad score of 1 to 2 was considered low quality, and a Jadad score of 3 to 5 was considered high quality. Moreover, the Schulz hidden grouping was described as 'adequate' 'inadequate' and 'unclear'.

Statistical analysis. Results of the studies included are reported as the number of observations, ratio or mean \pm standard deviation. When the result was reported as the standard error, the standard deviation was calculated from the standard error.

Data analysis and graph synthesis were performed by RevMan (version 5.2; The Cochrane Collaboration, Oxford, UK). Continuous outcomes, including the reduction in HVPG between the control and experimental groups were reported as a weighted mean difference (WMD) with a $95 \%$ confidence interval (CI). Moreover, heterogeneity was assessed using the $\chi^{2}$ test and $\mathrm{I}^{2}$-values (15). $\chi^{2}$ statistics $\mathrm{P}>0.1$ were considered to have no heterogeneity. Moreover, $\mathrm{I}^{2}$-values $<25 \%$ were considered to have a low risk, $25-50 \%$ was considered a moderate risk and values $>50 \%$ were considered to have a high risk of heterogeneity. If there was significant heterogeneity, potential reasons for the heterogeneity were explored and combinability of trials was reassessed, respectively.

The WMD in the heart rate and MAP between the treatment and control groups was also assessed as a measure of an adverse effect.

\section{Results}

Study selection. The search was conducted in July 2015, and a total of 64 abstracts were identified. The full-text of 61 of these pertinent reports were reviewed, respectively. In total, 58 articles were excluded for the following reasons: i) They did not compare the RAAS inhibitor and $\beta$-blocker combination therapy with $\beta$-blocker monotherapy (24/61) (16-39); ii) there was no cirrhosis (17/61) (40-56); iii) there was a lack of HVPG measurements (4/61) (57-60); and iv) there were no RCTs (13/61) (61-73). The remaining three articles (8-10) met the inclusion criteria (Fig. 1).

Description of studies included. The characteristics of the studies included are summarized in Table I. A total of three studies comparing the RAAS inhibitor and $\beta$-blocker combination therapy with $\beta$-blocker monotherapy were included. In one study (8), the treated group was administered propranolol $40 \mathrm{mg}$ bid and spironolactone $100 \mathrm{mg}$ qd, while the control group was administered propranolol at a dose of $40 \mathrm{mg}$ bid and a placebo tablet. Moreover, the dose of propranolol was gradually increased until there was a decrease in pulse rate of $>20 \%$ from the baseline, or a pulse rate of 60 beats per minute was achieved. Hemodynamic measurements were repeated after eight days of treatment. In another study (9), the treated group was administered irbesartan at a starting dose of $75 \mathrm{mg} /$ day followed by a step-up dose to $300 \mathrm{mg} /$ day (mean dose, $271.9 \pm 13.1 \mathrm{mg} /$ day) with propranolol $20 \mathrm{mg}$ bid, while the control group was administered propranolol $20 \mathrm{mg}$ bid. Hemodynamic measurements were repeated after eight weeks of treatment. In the remaining study (10), the treated group was administered spironolactone $100 \mathrm{mg} /$ day with a mean dose of nadolol of $76 \pm 62 \mathrm{mg} /$ day, while the control group was administered a mean dose of nadolol $80 \pm 60 \mathrm{mg} /$ day. Moreover, a hemodynamic study was conducted after 2-3 months of treatment.

The characteristics of the 91 patients included are summarized in Table II. The mean patient age was 52.2 years. In total, only two studies $(8,9)$ mentioned the gender ratio and Child-Pugh class. Moreover, $70 \%$ of patients were male, and 
Table I. Characteristics of the trials included.

\begin{tabular}{|c|c|c|c|c|}
\hline Author, year & Monotherapy group & Combination group & $\begin{array}{l}\text { Time of HVPG } \\
\text { assessment }\end{array}$ & Ref \\
\hline De, 2008 & $\begin{array}{l}\text { Propranolol } 40 \mathrm{mg} \text { twice daily } \\
\text { (mean dose, } 92.94 \pm 23.39 \mathrm{mg} / \text { day) }\end{array}$ & $\begin{array}{l}\text { Spironolactone } 100 \mathrm{mg} / \text { day } \\
\text { + propranolol } 40 \mathrm{mg} \text { twice daily } \\
\text { (mean dose, } 88.89 \pm 20.83 \mathrm{mg} / \text { day) }\end{array}$ & 8 days & (8) \\
\hline Schepke, 2008 & Propranolol 20 mg b.i.d & $\begin{array}{l}\text { Irbesartan (step-up dosage titration } \\
\text { up to } 300 \mathrm{mg} / \text { day) (mean dose } \\
271.9 \pm 13.1 \mathrm{mg} / \text { day)+propranolol } \\
20 \mathrm{mg} \text { b.i.d }\end{array}$ & 8 weeks & (9) \\
\hline Abecasis, 2003 & $\begin{array}{l}\text { Nadolol (mean dose, } \\
80 \pm 60 \mathrm{mg} / \text { day })\end{array}$ & $\begin{array}{l}\text { Spironolactone (100 mg/day)+nadolol } \\
\text { (mean dose, } 76 \pm 62 \mathrm{mg} / \text { day) }\end{array}$ & 8-12 weeks & $(10)$ \\
\hline
\end{tabular}

HVPG, hepatic venous pressure gradient.

Table II. Characteristics of participants in the studies included.

\begin{tabular}{|c|c|c|c|c|c|c|c|c|}
\hline Author, year & $\begin{array}{l}\text { Treatment } \\
\text { group }\end{array}$ & $\begin{array}{c}\text { Patients, } \\
\mathrm{n}\end{array}$ & $\begin{array}{l}\text { Age, years } \\
(\text { mean } \pm \mathrm{SD})\end{array}$ & $\begin{array}{l}\text { Gender ratio, } \\
\text { male/female }\end{array}$ & $\begin{array}{l}\text { Child-Pugh } \\
\text { class, A/B/C }\end{array}$ & $\begin{array}{c}\text { Previous portal } \\
\text { hypertension- } \\
\text { related bleeding, \% }\end{array}$ & $\begin{array}{c}\text { Ascites, } \\
\%\end{array}$ & Ref \\
\hline \multirow[t]{2}{*}{ De, 2008} & Monotherapy & 17 & $44.3 \pm 7.98$ & $12 / 5$ & $3 / 8 / 6$ & 100 & 58.82 & \multirow[t]{2}{*}{ (8) } \\
\hline & Combination & 18 & $46.61 \pm 8.71$ & $15 / 3$ & $4 / 9 / 5$ & 100 & 44.44 & \\
\hline \multirow[t]{2}{*}{ Schepke, 2008} & Monotherapy & 15 & $55.8 \pm 3.6$ & $10 / 5$ & $7 / 7 / 1$ & 40 & 26.67 & \multirow[t]{2}{*}{ (9) } \\
\hline & Combination & 17 & $51.7 \pm 2.5$ & $10 / 7$ & $6 / 11 / 0$ & 41.18 & 41.18 & \\
\hline \multirow[t]{2}{*}{ Abecasis, 2003} & Monotherapy & 12 & $56 \pm 10$ & NR & NR & 0 & 0 & \multirow[t]{2}{*}{$(10)$} \\
\hline & Combination & 12 & $59 \pm 11$ & NR & NR & 0 & 0 & \\
\hline
\end{tabular}

SD, standard deviation; Monotherapy, $\beta$-blockers monotherapy; Combined, RAAS inhibitor and $\beta$-blocker combination therapy; NR, not reported.

the Child-Pugh class A/B/C was 20/35/12, respectively. In addition, the proportion of patients with previous esophageal variceal hemorrhage was 29 of 91 (31.87\%), and 48 of 91 $(52.75 \%)$ patients previously had ascites.

Methodological quality. The methodological quality of the included articles is listed in Table III. All three articles obtained a Jadad score of 5, two studies had adequate allocation concealment and one study had unclear allocation concealment, which revealed that all three studies were of high quality.

\section{Outcome evaluation}

Mean change in the HVPG. The pooled WMD of HVPG reductions in the two groups was $1.70(0.52,2.88$; fixed-effect model), test for overall effect: $\mathrm{Z}=2.83(\mathrm{P}=0.005)$, indicating a significantly higher HVPG reduction with the RAAS inhibitor and $\beta$-blocker combination therapy compared to $\beta$-blocker monotherapy. Moreover, no heterogeneity was observed in the analysis of combination therapy vs. monotherapy $(\mathrm{P}=0.30$; $\mathrm{I}^{2}=17 \%$ ) (Fig. 2). As there were only three articles included, influence analysis was performed in order to study the effect of individual research on the total combined effect quantity. The result revealed that the second article (8) has a large influence on the total consolidation effect quantity (Fig. 3).

A total of 26 of 46 patients (56.52\%) in the RAAS inhibitor and $\beta$-blocker combination therapy group and 17 of 44 patients (38.64\%) in the $\beta$-blocker monotherapy group revealed a hemodynamic response. The pooled relative risk of achieving a hemodynamic response in the two groups was $1.46(0.93,2.30$; fixed-effect model), indicating that there was no significant difference between the hemodynamic response with RAAS inhibitor plus $\beta$-blocker combination therapy and $\beta$-blocker monotherapy. Moreover, no heterogeneity was identified in the pooled analysis of the trials $\left(\mathrm{P}=0.26 ; \mathrm{I}^{2}=26 \%\right.$ ) (Fig. 4).

Adverse events. The pooled WMD in the heart rate change in the two groups was $-0.11(-3.51,3.29$; fixed-effect model), test for overall effect: $\mathrm{Z}=0.06(\mathrm{P}=0.95)$, indicating that there was no significant heart rate change with the RAAS inhibitor plus $\beta$-blocker combination therapy and $\beta$-blocker monotherapy. Moreover, no heterogeneity was identified $\left(\mathrm{P}=0.31 ; \mathrm{I}^{2}=14 \%\right)$ (Fig. 5).

In the studies by Abecasis et al (10) and Schepke et al (9), there was a significant change in the MAP between the two treatment groups. However, the RAAS inhibitor and 
Table III. Methodological quality assessment of the trials included.

\begin{tabular}{|c|c|c|c|c|c|c|}
\hline Author, year & $\begin{array}{l}\text { Generation of the } \\
\text { allocation sequence }\end{array}$ & Blinding & $\begin{array}{c}\text { Dropouts and } \\
\text { withdrawals }\end{array}$ & Jadad score & $\begin{array}{l}\text { Allocation } \\
\text { concealment }\end{array}$ & Ref \\
\hline De, 2008 & 2 & 2 & 1 & 5 & Adequate & (8) \\
\hline Schepke, 2008 & 2 & 2 & 1 & 5 & Adequate & (9) \\
\hline Abecasis, 2003 & 2 & 2 & 1 & 5 & Unclear & (10) \\
\hline
\end{tabular}

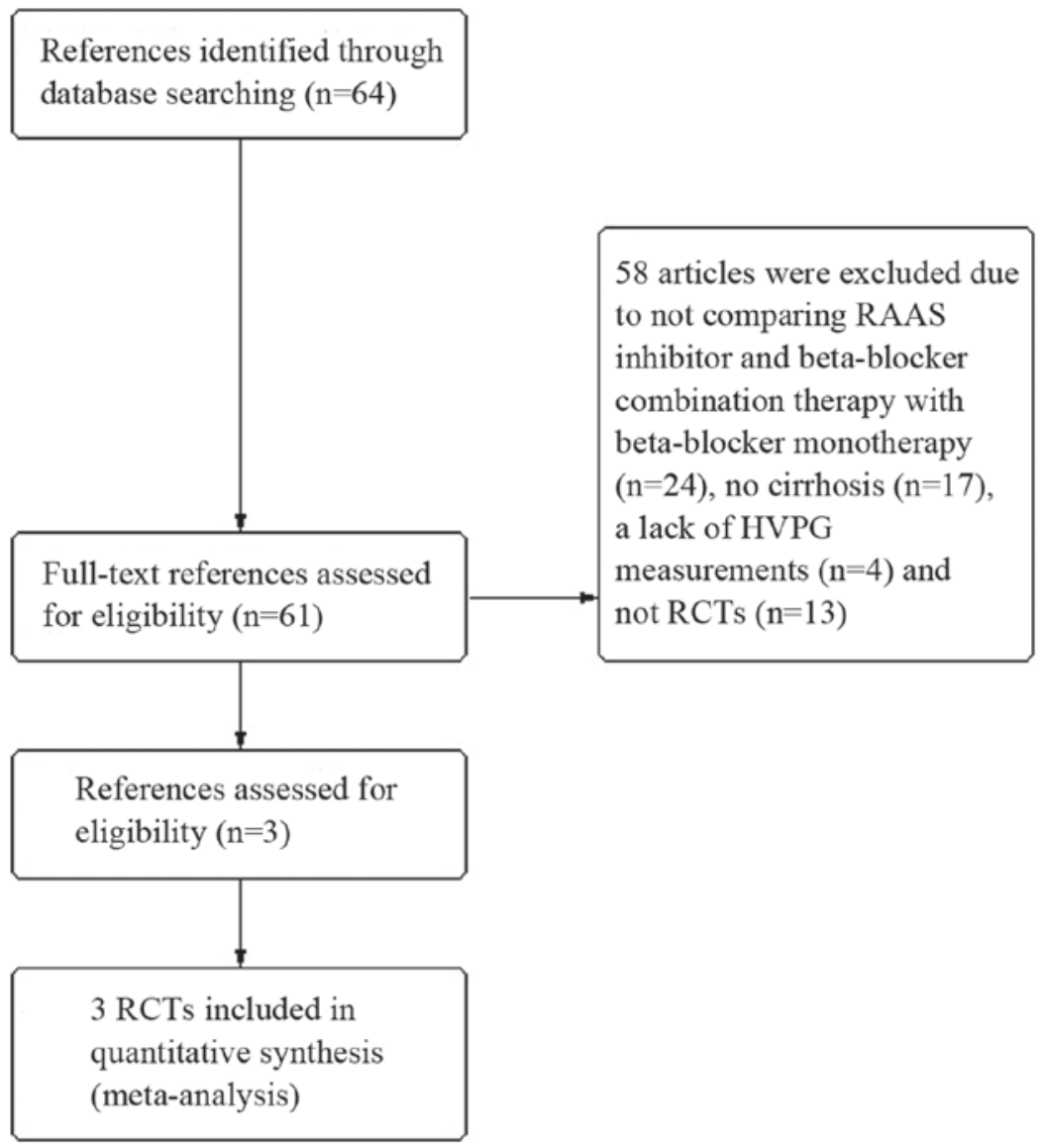

Figure 1. Flow diagram of the studies included in the meta-analysis. RAAS, renin-angiotensin-aldosterone system; HVPG, hepatic venous pressure gradient; RCT, randomized controlled trials.

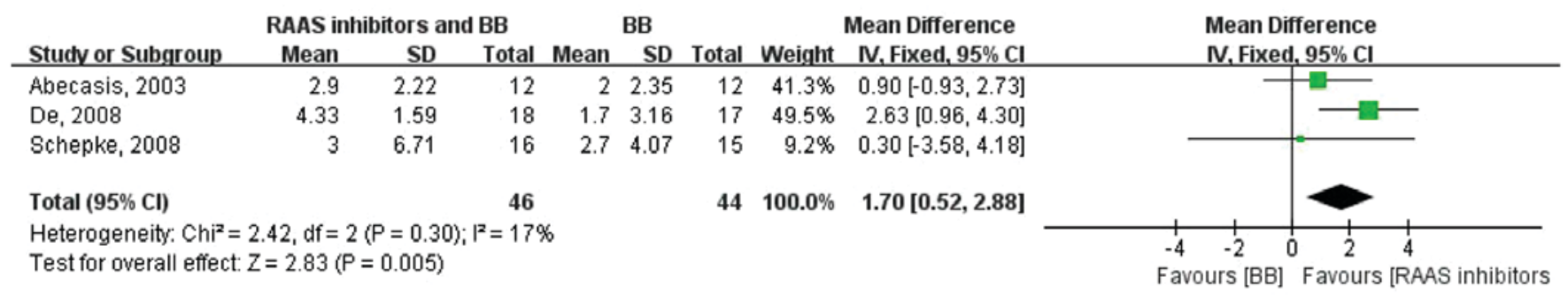

Figure 2. Change in portal pressure: RAAS inhibitor and BB combination therapy vs. BB monotherapy treatment. RAAs, renin-angiotensin-aldosterone system; BB, $\beta$-blocker; SD, standard deviation; CI, confidence interval.

$\beta$-blocker combination therapy reduced MAP to a greater extent compared to $\beta$-blocker monotherapy. Moreover, the pooled WMD was 9.50 (4.12, 14.89; fixed-effect model), and no heterogeneity was identified $\left(\mathrm{P}=0.80 ; \mathrm{I}^{2}=0 \%\right)$ (Fig. 6). In the study by Schepke et al (9), one patient in the combination therapy group suffered severe esophageal variceal bleeding 


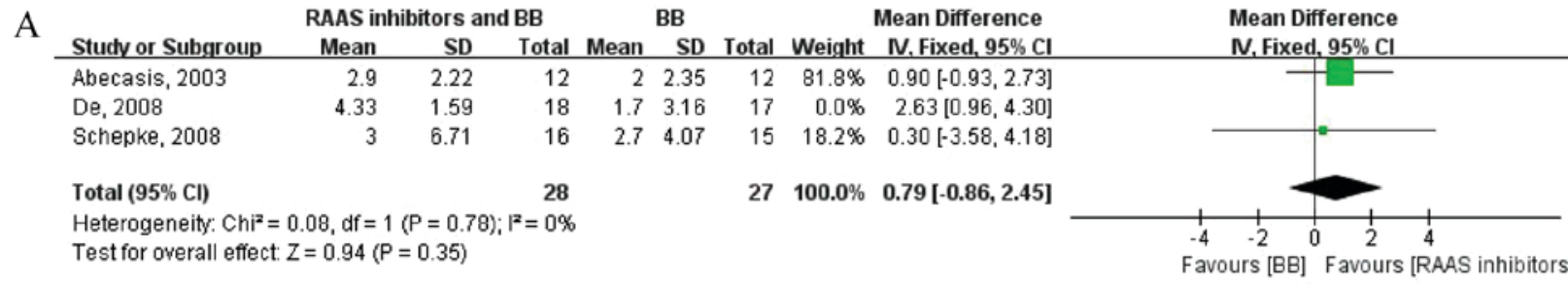

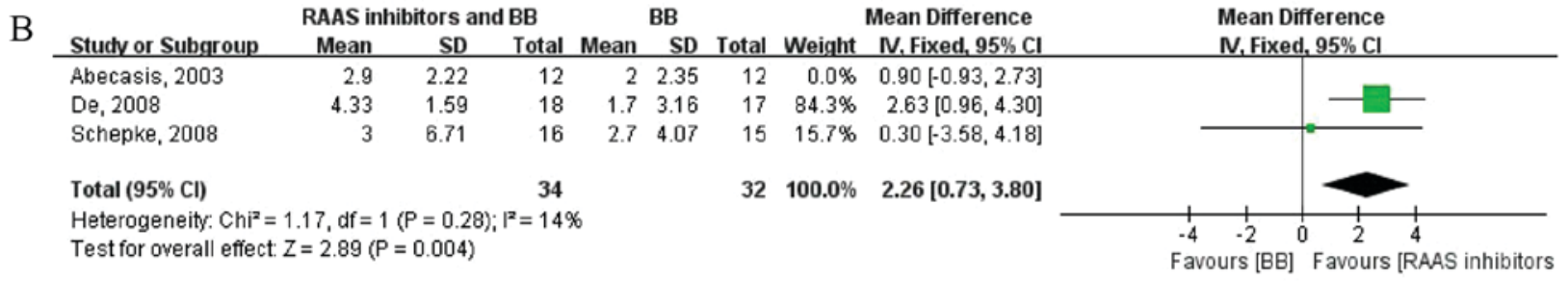

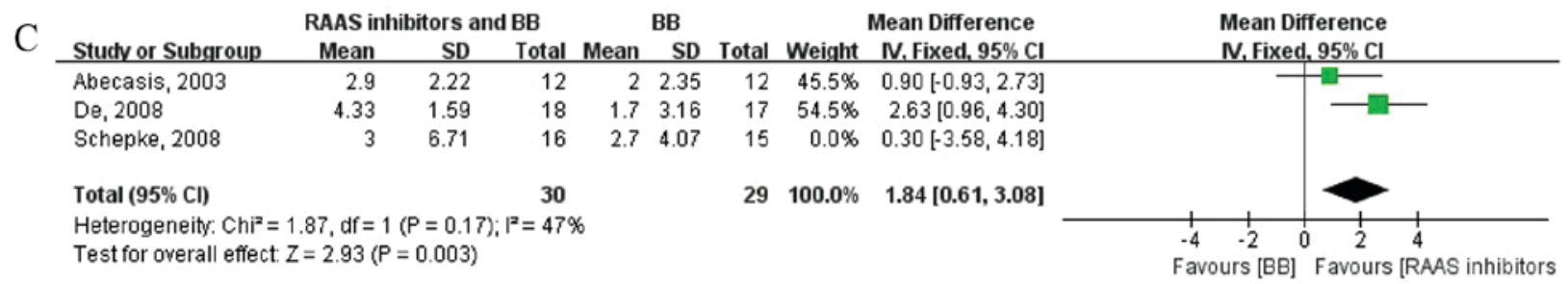

Figure 3. Sensitivity analysis. (A) Study the effect of individual research (Abecasis, 2003) on total combined effect quantity. (B) Study the effect of individual research (De, 2008) on total combined effect quantity. (C) Study the effect of individual research (Schepke, 2008) on total combined effect quantity. RAAS, renin-angiotensin-aldosterone system; BB, $\beta$-blocker; $\mathrm{SD}$, standard deviation; $\mathrm{CI}$, confidence interval.

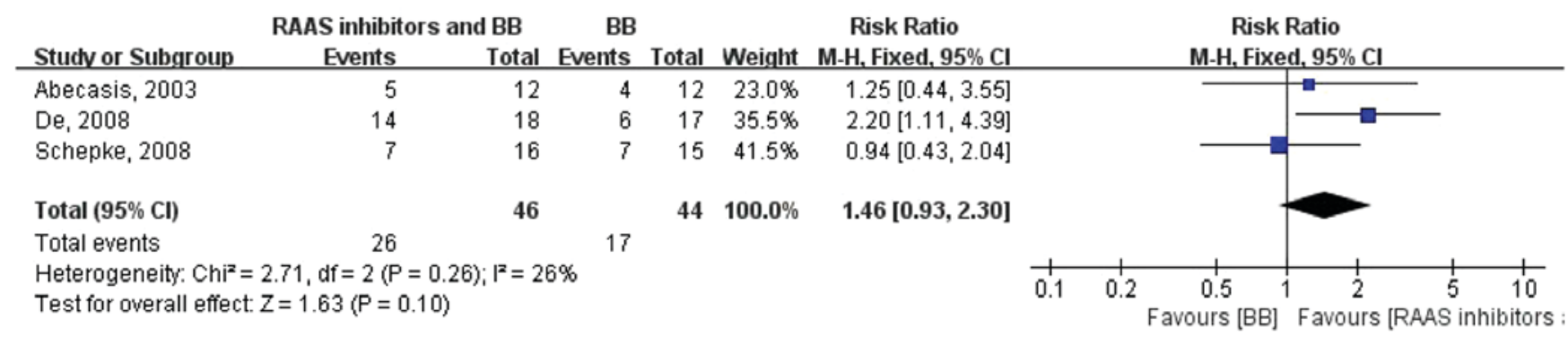

Figure 4. Relative risk of treatment response (reduction in hepatic venous pressure gradient of $\geq 20 \%$ of baseline or to $<12 \mathrm{mmHg}$ achieved) with RAAS inhibitor and BB combination therapy compared with BB monotherapy. RAAS, renin-angiotensin-aldosterone system; BB, $\beta$-blocker; CI, confidence interval.

following five weeks of treatment. Thus, the hemodynamic measurements were not repeated. In total, four patients reported minor dizziness in the RAAS inhibitor and $\beta$-blocker combination therapy group, which was thought to be associated with the hypotensive effects of the RAAS inhibitor.

\section{Discussion}

There are three main aspects in the pathophysiology of portal hypertension (74). The first is structural changes caused by fibrosis, vascular occlusion and regenerative nodule formation or remodeling. The second aspect is sinusoidal endothelial dysfunction and contraction of stellate cells, which further increases $20-30 \%$ of the intrahepatic resistance. Finally, the third aspect is splanchnic vasodilatation and hyperkinetic circulation, which maintains and worsens portal hypertension.
Currently, $\beta$-blockers have become the recommended medicine for the therapy of portal hypertension, which decrease portal pressure in two main ways. Firstly, they block $\beta-1$ cardiac receptors, which results in decreased cardiac output and MAP (75). Secondly, $\beta$-blockers function by blocking $\beta-2$ vascular receptors, leading to splanchnic vasoconstriction results from the unopposed effect of alpha-1 receptors (76). In recent years, studies $(4,6,24,77)$ have increasingly revealed that the RAAS system is important in the pathophysiology of portal hypertension.

Angiotensin II is a vasoconstrictor, which has an elevated serum concentration in patients with cirrhosis. A prior study (4), which investigated the effect of angiotensin II on activated human hepatic stellate cells, demonstrated that angiotensin II can increase cell contraction and proliferation, which were rarely detected in resting cells. These results indicate that angiotensin II induces hepatic stellate cell activation 


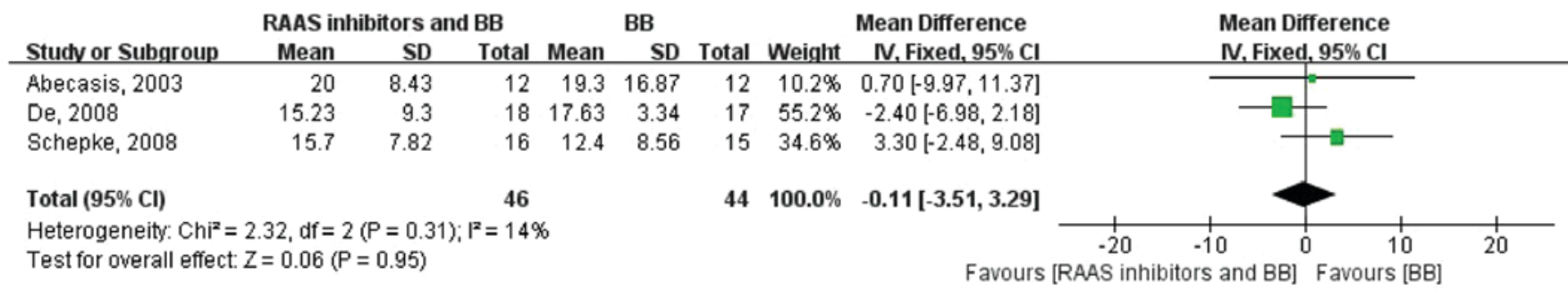

Figure 5. Change in heart rate: RAAS inhibitor and BB combination therapy vs. BB monotherapy treatment. RAAS, renin-angiotensin-aldosterone system; $\mathrm{BB}, \beta$-blockeçr; SD, standard deviation; $\mathrm{CI}$, confidence interval.

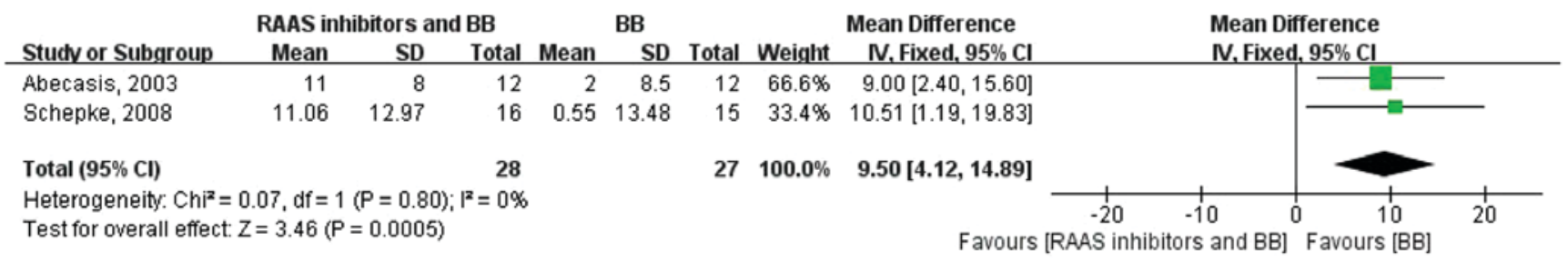

Figure 6. Change in mean arterial pressure: RAAS inhibitor and BB combination therapy vs. BB monotherapy treatment. RAAS, renin-angiotensin-aldosterone system; BB, $\beta$-blocker; SD, standard deviation; CI, confidence interval.

in order to increase intrahepatic resistance. In addition, angiotensin type1 (AT1) receptor antagonists were reported to reduce the progression of hepatic fibrosis and decrease portal pressure in rats (77). A previous study investigated the long-term effects of the AT1 receptor on portal hypertension and demonstrated that $25 \%$ of patients achieved a reduction $>20 \%$. Moreover, HVPG significantly decreased in the treated group $(-8.4 \% \pm 2.4)$ vs. $(+5.6 \% \pm 2.9)$ in the controlled group (21). In addition to the effect of decreasing portal vein pressure by reducing the plasma volume and the vascular relaxing activity (24), aldosterone antagonist has also been reported to suppress inflammation, improve endothelial dysfunction, reduce oxidative stress, decrease insulin resistance and slow down the progress of liver fibrosis (6).

Since only $30-40 \%$ of the patients under long-term therapy with $\beta$-blockers achieve a good hemodynamic response (3), it is hypothesized that the RAAS inhibitor and $\beta$-blocker combination therapy may achieve a better effect.

The present meta-analysis aimed to assess the efficacy of the RAAS inhibitor and $\beta$-blocker combination therapy compared with $\beta$-blocker monotherapy on HVPG reduction in patients with cirrhosis. The results demonstrated that the RAAS inhibitor and $\beta$-blocker combination therapy reduced HVPG to a more significant extent compared to $\beta$-blocker monotherapy. In addition, the pooled WMD between HVPG reduction with RAAS inhibitor plus $\beta$-blocker combination therapy and $\beta$-blocker monotherapy was 1.70 (95\% CI: $0.52-2.88$ ), and no heterogeneity was identified.

The number of patients achieving a hemodynamic response was reported in all studies included and was higher with the RAAS inhibitor and $\beta$-blocker combination therapy (26/46 vs. 17/44). However, there were no significant differences in the pooled relative risk of achieving a hemodynamic response with RAAS inhibitor and $\beta$-blocker combination therapy compared with $\beta$-blocker monotherapy (1.46; 95\% CI: 0.93-2.30).
Only one study (9) completely described the adverse events. In total, four patients reported minor dizziness in the RAAS inhibitor and $\beta$-blocker combination therapy group, which may have been associated with the hypotensive effects of the RAAS inhibitor. A previous article comparing irbesartan with placebo in patients with cirrhosis (78) confirmed that the activation of RAAS is associated to circulatory complications. Thus, a low starting dose followed by a slow step-up dose of the RAAS inhibitor may be recommended to prevent hypotension. Moreover, the pooled mean weighed change in the heart rate in the two groups was -0.11 (95\% CI: $-3.51-3.29)$, indicating that the difference in heart rate change between the two groups was not statistically significant. These observations demonstrate that the RAAS inhibitor and $\beta$-blocker combination therapy does not increase the change in heart rate compared with $\beta$-blocker monotherapy. In two of the studies included $(9,10)$, MAP was measured before and after treatment. The pooled WMD of MAP change in the two groups was 9.50 (95\% CI: 4.12-14.89), indicating that the RAAS inhibitor and $\beta$-blocker combination therapy reduced MAP more than $\beta$-blocker monotherapy.

Nevertheless, there are many limitations in the present study. Firstly, the number of available studies and patients included was too small, which mitigated the achievement of satisfactory results. Secondly, the course of the selected trials was not the same, and the span was large. In addition, angiotensin I-converting enzyme inhibitors, angiotensin receptor blockers and aldosterone antagonists were regarded as the same drugs to be analyzed, while they function through different targets, which may result in a different hemodynamic response. However, despite these limitations, to the best of our knowledge the present study is the first meta-analysis comparing the RAAS inhibitor and $\beta$-blocker combination therapy with the $\beta$-blocker monotherapy effect on portal pressure, and included all high quality randomized controlled trials. 
In conclusion, the RAAS inhibitor and $\beta$-blocker combination therapy reduces portal hypertension to a more significant extent than $\beta$-blocker monotherapy. Although both therapies reduced the heart rate to similar levels, the RAAS inhibitor and $\beta$-blocker combination therapy reduced the MAP to a greater extent compared to $\beta$-blocker monotherapy. Further larger-scale trials are required in order to determine the efficacy and safety of the RAAS inhibitor and $\beta$-blocker combination therapy for the reduction of HVPG in patients with cirrhosis.

\section{Acknowledgements}

The present study was supported by the Shanghai Health System Important Disease Joint Research Project (grant no. 2014ZYJB0201).

\section{References}

1. Feu F, García-Pagín JC, Bosch J, Luca A, Terés J, Escorsell A and Rodés J: Relation between portal pressure response to pharmacotherapy and risk of recurrent variceal haemorrhage in patients with cirrhosis. Lancet 346: 1056-1059, 1995.

2. Groszmann RJ, Bosch J, Grace ND, Conn HO, Garcia-Tsao G, Navasa M, Alberts J, Rodes J, Fischer R, Bermann M, et al: Haemodynamic events in a prospective randomized trial of propranolol versus placebo in the prevention of a first variceal hemorrhage. Gastroenterology 99: 1401-1407, 1990.

3. Garcia-Tsao G and Bosch J: Management of varices and variceal hemorrhage in cirrhosis. N Engl J Med 362: 823-832, 2010

4. Bataller R, Ginès P, Nicolás JM, Görbig MN, Garcia-Ramallo E, Gasull X, Bosch J, Arroyo V and Rodés J: Angiotensin II induces contraction and proliferation of human hepatic stellate cells. Gastroenterology 118: 1149-1156, 2000.

5. Garcia-Pagán JC, Salmerón JM, Feu F, Luca A, Ginés P, Pizcueta P, Claria J, Piera C, Arroyo V, Bosch J, et al: Effects of low-sodium diet and spironolactone on portal pressure in patients with compensated cirrhosis. Hepatology 19: 1095-1099, 1994.

6. Sowers JR, Whaley-Connell A and Epstein M: Narrative review: The emerging clinical implications of the role of aldosterone in the metabolic syndrome and resistant hypertension. Ann Intern Med 150: 776-783, 2009 .

7. Tandon P, Abraldes JG, Berzigotti A, Garcia-Pagan JC and Bosch J: Renin-angiotensin-aldosterone inhibitors in the reduction of portal pressure: A systematic review and meta-analysis. J Hepatol 53: 273-282, 2010.

8. De BK, Dutta D, Som R, Biswas PK, Pal SK and Biswas A: Haemodynamic effects of propranolol with spironolactone in patients with variceal bleeds: A randomized controlled trial. World J Gastroenterol 14: 1908-1913, 2008.

9. Schepke M, Wiest R, Flacke S, Heller J, Stoffel-Wagner B, Herold T, Ghauri M and Sauerbruch T: Irbesartan plus low-dose propranolol versus low-dose propranolol alone in cirrhosis: A placebo-controlled, double-blind study. Am J Gastroenterol 103: 1152-1158, 2008.

10. Abecasis R, Kravetz D, Fassio E, Ameigeiras B, Garcia D, Isla R, Landeira G, Dominguez N, Romero G, Argonz J and Terg R: Nadolol plus spironolactone in the prophylaxis of first variceal bleed in nonascitic cirrhotic patients: A preliminary study. Hepatology 37: 359-365, 2003.

11. Zhang H, Yang J, Zhu R, Zheng Y, Zhou Y, Dai W, Wang F, Chen K, Li J, Wang C, et al: Combination therapy of ursodeoxycholic acid and budesonide for PBC-AIH overlap syndrome: A meta-analysis. Drug Des Devel Ther 9: 567-574, 2015.

12. Zhang Y, Li S, He L, Wang F, Chen K, Li J, Liu T, Zheng Y, Wang J, Lu W, et al: Combination therapy of fenofibrate and ursodeoxycholic acid in patients with primary biliary cirrhosis who respond incompletely to UDCA monotherapy: A meta-analysis. Drug Des Devel Ther 9: 2757-2766, 2015.

13. Kjaergard LL, Villumsen J and Gluud C: Reported methodologic quality and discrepancies between large and small randomized trials in meta-analyses. Ann Intern Med 135: 982-989, 2001.

14. Gluud LL: Bias in clinical intervention research. Am J Epidemiol 163: 493-501, 2006.
15. Higgins JP, Thompson SG, Deeks JJ and Altman DG: Measuring inconsistency in meta-analyses. BMJ 327: 557-560, 2003.

16. Sen S, De BK, Biswas PK, Biswas J, Das D and Maity AK: Haemodynamic effect of spironolactone in liver cirrhosis and propranolol-resistant portal hypertension. Indian $\mathrm{J}$ Gastroenterol 21: 145-148, 2002.

17. Winkler C, Hobolth L, Krag A, Bendtsen F and Møller S: Effects of treatment with $\beta$-blocker and aldosterone antagonist on central and peripheral haemodynamics and oxygenation in cirrhosis. Eur J Gastroenterol Hepatol 23: 334-342, 2011.

18. De BK, Bandyopadhyay K, Das TK, Das D, Biswas PK, Majumdar D, Mandal SK, Ray S and Dasgupta S: Portal pressure response to losartan compared with propranolol in patients with cirrhosis. Am J Gastroenterol 98: 1371-1376, 2003.

19. Castano G, Viudez P, Riccitelli M and Sookoian S: A randomized study of losartan vs propranolol: Effects on hepatic and systemic haemodynamics in cirrhotic patients. Ann Hepatol 2: 36-40, 2003.

20. Agasti AK, Mahajan AU, Phadke AY, Nathani PJ and Sawant P: Comparative randomized study on efficacy of losartan versus propranolol in lowering portal pressure in decompensated chronic liver disease. J Dig Dis 14: 266-271, 2013.

21. Debernardi-Venon W, Martini S, Biasi F, Vizio B, Termine A, Poli G, Brunello F, Alessandria C, Bonardi R, Saracco G, et al: AT1 receptor antagonist Candesartan in selected cirrhotic patients: Effect on portal pressure and liver fibrosis markers. J Hepatol 46: 1026-1033, 2007.

22. Gonzalez-Abraldes J, Albillos A, Bañares R, Del Arbol LR, Moitinho E, Rodríguez C, González M, Escorsell A García-Pagán JC and Bosch J: Randomized comparison of long-term losartan versus propranolol in lowering portal pressure in cirrhosis. Gastroenterology 121: 382-388, 2001.

23. Venon WD, Baronio M, Leone N, Rolfo E, Fadda M, Barletti C, Todros L, Saracco G and Rizzetto M: Effects of long-term Irbesartan in reducing portal pressure in cirrhotic patients: Comparison with propranolol in a randomised controlled study. J Hepatol 38: 455-460, 2003.

24. Nevens F, Lijnen P, VanBilloen H and Fevery J: The effect of long-term treatment with spironolactone on variceal pressure in patients with portal hypertension without ascites. Hepatology 23: 1047-1052, 1996.

25. Vilas-Boas WW, Ribeiro-Oliveira A Jr, Ribeiro Rda C, Vieira RL, Almeida J, Nadu AP, Simões e Silva AC and Santos RA: Effect of propranolol on the splanchnic and peripheral renin angiotensin system in cirrhotic patients. World J Gastroenterol 14: 6824-6830, 2008.

26. Pagliaro L: Lebrec D, Poynard T, Hillon P, Benhamou J-P. Propranolol for prevention of recurrent gastrointestinal bleeding in patients with cirrhosis. A controlled study [N Engl J Med 1981;305:1371-1374]. J Hepatol 36: 148-150, 2002.

27. Shah HA, Azam Z, Rauf J, Abid S, Hamid S, Jafri W, Khalid A, Ismail FW, Parkash O, Subhan A and Munir SM: Carvedilol vs. esophageal variceal band ligation in the primary prophylaxis of variceal hemorrhage: A multicentre randomized controlled trial. J Hepatol 60: 757-764, 2014.

28. Lazebnik LB, Mikheeva OM, Toporkov AS, Komissarenko IA, Vasnev OS and Fedulenkova LV: Correction of portal hypertension by beta-adrenoblockers (atenolol and metoprolol) and inhibitors of ACE (lisinopril and enalapril) in liver cirrhosis. Eksp Klin Gastroenterol: 57-66, 2007.

29. Wagatsuma Y, Naritaka Y, Shimakawa T, Kanako H, Keiichiro I, Shunichi S, Konno S, Katsube T and Ogawa K: Clinical usefulness of the angiotensin II receptor antagonist losartan in patients with portal hypertensive gastropathy. Hepatogastroenterology 53: 171-174, 2006.

30. Baik SK, Park DH, Kim MY, Choi YJ, Kim HS, Lee DK, Kwon SO, Kim YJ, Park JW and Chang SJ: Captopril reduces portal pressure effectively in portal hypertensive patients with low portal venous velocity. J Gastroenterol 38: 1150-1154, 2003.

31. Klein CG: Medicinal influence on portal vein haemodynamics by cirrhosis of the liver-comparison between angiotensin II receptor antagonists and $\beta$-blockers in combination with spironolactone. J Zeitschrift fur Gastroenterologie 39: 669, 2001.

32. Alessandria C, Elia C, Mezzabotta L, Risso A, Andrealli A, Spandre M, Morgando A, Marzano A and Rizzetto M: Prevention of paracentesis-induced circulatory dysfunction in cirrhosis: Standard vs half albumin doses. A prospective, randomized, unblinded pilot study. Dig Liver Dis 43: 881-886, 2011. 
33. Block JP: Rifaximin improves the treatment of hepatic encephalopathy. J Clin Outcomes Manage 17: 202-204, 2010.

34. Bass NM, Mullen KD, Sanyal A, Poordad F, Neff G, Leevy CB, Sigal S, Sheikh MY, Beavers K, Frederick T, et al: Rifaximin treatment in hepatic encephalopathy. N Engl J Med 362: 1071-1081, 2010.

35. Van den Velde S, Nevens F, Van hee P, van Steenberghe D and Quirynen M: GC-MS analysis of breath odor compounds in liver patients. J Chromatogr B Analyt Technol Biomed Life Sci 875: 344-348, 2008.

36. Hsien L, Breddemann A, Frobel AK, Heusch A, Schmidt KG and Läer S: Off-label drug use among hospitalised children: Identifying areas with the highest need for research. Pharm World Sci 30: 497-502, 2008

37. Revill P, Serradell N, Bolós J and Bayes M: Satavaptan. Drug Fut 32: 26-36, 2007

38. Merkel C: Nonselective beta-blockers plus nitrates in portal hypertension: An open question. Hepatology 37: 1254-1256, 2003.

39. Merkel C, Sacerdoti D, Bolognesi M, et al: Pharmacological associations in the primary/prophylaxis of variceal bleeding in cirrhosis. Giornale Italiano di Endoscopia Digestiva 21: 1-5, 1998

40. Fox K, Ford I, Steg PG, Tardif JC, Tendera M and Ferrari R; SIGNIFY Investigators: Ivabradine in stable coronary artery disease without clinical heart failure. N Engl J Med 371: 1091-1099, 2014

41. Trošt Rupnik A, Pajek J, Guček A, Osredkar J, Kovač D, Bren A, Klančič D, Saksida S, Rus I, Globokar M, et al: Influence of renin-angiotensin-aldosterone system-blocking drugs on peritoneal membrane in peritoneal dialysis patients. Ther Apher Dial 17: 425-430, 2013

42. Fallahzadeh MK, Dormanesh B, Sagheb MM, Roozbeh J, Vessal G, Pakfetrat M, Daneshbod Y, Kamali-Sarvestani E and Lankarani KB: Effect of addition of silymarin to renin-angiotensin system inhibitors on proteinuria in type 2 diabetic patients with overt nephropathy: A randomized, double-blind, placebo-controlled trial. Am J Kidney Dis 60: 896-903, 2012.

43. Kosmala W, Przewlocka-Kosmala M, Szczepanik-Osadnik H Mysiak A, O'Moore-Sullivan T and Marwick TH: A randomized study of the beneficial effects of aldosterone antagonism on LV function, structure, and fibrosis markers in metabolic syndrome. JACC Cardiovasc Imaging 4: 1239-1249, 2011.

44. Spinar J, Vitovec J and Spinarová L; Zastoupení resitelů studie FARIM: FARIM-FARmakoterapie po Infarktu Myokardu (Post-Myocardial Infarction Pharmacotherapy Study). Vnitrni lekarstvi 57: 778-784, 2011 (In Czech).

45. Guney I, Selcuk NY, Altintepe L, Atalay H, Başarali MK and Büyükbaş S: Antifibrotic effects of aldosterone receptor blocker (spironolactone) in patients with chronic kidney disease. Ren Fail 31: 779-784, 2009.

46. Tylicki L, Renke M, Rutkowski P, Larczyński W, Aleksandrowicz E, Lysiak-Szydlowska W and Rutkowski B: Dual blockade of the renin-angiotensin-aldosterone system with high-dose angiotensin-converting enzyme inhibitor for nephroprotection: An open, controlled, randomized study. Scand J Urol Nephrol 42: 381-388, 2008

47. Tylicki L, Rutkowski P, Renke M, Larczyński W, Aleksandrowicz E, Lysiak-Szydlowska W and Rutkowski B: Triple pharmacological blockade of the renin-angiotensin-aldosterone system in nondiabetic CKD: An open-label crossover randomized controlled trial. Am J Kidney Dis 52: 486-493, 2008.

48. Muller-Brunotte R, Kahan T, López B, Edner M, González A, Díez J and Malmqvist K: Myocardial fibrosis and diastolic dysfunction in patients with hypertension: Results from the Swedish Irbesartan Left Ventricular Hypertrophy Investigation versus Atenolol (SILVHIA). J Hypertens 25: 1958-1966, 2007.

49. Orea-Tejeda A, Colín-Ramírez E, Castillo-Martínez L, Asensio-Lafuente E, Corzo-León D, González-Toledo R, Rebollar-González V, Narváez-David R and Dorantes-García J: Aldosterone receptor antagonists induce favorable cardiac remodeling in diastolic heart failure patients. Rev Invest Clin 59: 103-107, 2007

50. Cavallari LH, Momary KM, Groo VL, Viana MA, Camp JR and Stamos TD: Association of beta-blocker dose with serum procollagen concentrations and cardiac response to spironolactone in patients with heart failure. Pharmacotherapy 27: 801-812, 2007.

51. Tylicki L, Biedunkiewicz B, Chamienia A, Wojnarowski K, Zdrojewski Z, Aleksandrowicz E, Lysiak-Szydlowska W and Rutkowski B: Renal allograft protection with angiotensin II type 1 receptor antagonists. Am J Transplant 7: 243-248, 2007.
52. Christensen MK, Olsen MH, Wachtell K, Tuxen C, Fossum E, Bang LE, Wiinberg N, Devereux RB, Kjeldsen SE, Hildebrandt P, et al: Does long-term losartan- vs atenolol-based antihypertensive treatment influence collagen markers differently in hypertensive patients? A LIFE substudy. Blood Press 15: 198-206, 2006

53. Ciulla MM, Paliotti R, Esposito A, Dìez J, López B, Dahlöf B, Nicholls MG, Smith RD, Gilles L, Magrini F and Zanchetti A: Different effects of antihypertensive therapies based on losartan or atenolol on ultrasound and biochemical markers of myocardial fibrosis: Results of a randomized trial. Circulation 110: 552-557, 2004.

54. Hallberg P, Lind L, Billberger K, Michaelsson K, Karlsson J, Kurland L, Kahan T, Malmqvist K, Ohman KP, Nyström F, et al: Transforming growth factor betal genotype and change in left ventricular mass during antihypertensive treatment-results from the Swedish Irbesartan Left Ventricular Hypertrophy Investigation versus Atenolol (SILVHIA). Clin Cardiol 27: 169-173, 2004

55. el-Agroudy AE, Hassan NA, Foda MA, Ismail AM, el-Sawy EA, Mousa $\mathrm{O}$ and Ghoneim MA: Effect of angiotensin II receptor blocker on plasma levels of TGF-beta 1 and interstitial fibrosis in hypertensive kidney transplant patients. Am J Nephrol 23: 300-306, 2003

56. Hayashi M, Tsutamoto T, Wada A, Tsutsui T, Ishii C, Ohno K, Fujii M, Taniguchi A, Hamatani T, Nozato Y, et al: Immediate administration of mineralocorticoid receptor antagonist spironolactone prevents post-infarct left ventricular remodeling associated with suppression of a marker of myocardial collagen synthesis in patients with first anterior acute myocardial infarction. Circulation 107: 2559-2565, 2003.

57. Yang YY, Lin HC, Lee WP, Chu CJ, Lin MW, Lee FY, Hou MC, Jap JS and Lee SD: Association of the G-protein and $\alpha 2$-adrenergic receptor gene and plasma norepinephrine level with clonidine improvement of the effects of diuretics in patients with cirrhosis with refractory ascites: A randomised clinical trial. Gut 59: 1545-1553, 2010.

58. Ljubicić N, Bilić A and Plavsić V: Effect of propranolol on urinary prostaglandin E2 excretion and renal interlobar arterial blood flow after furosemide administration in patients with hepatic cirrhosis. Eur J Clin Pharmacol 43: 555-558, 1992.

59. Mikheeva OM, Drozdov VN and Komisarenko IA: Pharmacokinetic and pharmacodynamic characteristics of antihypertensive drugs in the treatment of hypertensive patients with chronic diseases of the liver. Ter Arkh 83: 49-55, 2011

60. Mikheeva OM: Pharmacokinetic and pharmacodynamic features of hypertensive drugs in treatment of patients with arterial hypertension associated with liver disease. Eksp Klin Gastroenterol: 95-101, 2010 (In Russian).

61. Nevens F: Non-invasive variceal pressure measurements: Validation and clinical implications. Verh K Acad Geneeskd Belg 58: 413-437, 1996.

62. Talwalkar JA and Kamath PS: Influence of recent advances in medical management on clinical outcomes of cirrhosis. Mayo Clin Proc 80: 1501-1508, 2005

63. Yang JD and Kim WR: Surveillance for hepatocellular carcinoma in patients with cirrhosis. Clin Gastroenterol Hepatol 10: 16-21, 2012.

64. Lubel JS, Herath CB, Burrell LM and Angus PW: Liver disease and the renin-angiotensin system: Recent discoveries and clinical implications. J Gastroenterol Hepatol 23: 1327-1338, 2008.

65. Albillos A: Preventing first variceal hemorrhage in cirrhosis. J Clin Gastroenterol 41: (Suppl 3): S305-S311, 2007.

66. Garcia-Tsao G, Sanyal AJ, Grace ND and Carey W; Practice Guidelines Committee of the American Association for the Study of Liver Diseases; Practice Parameters Committee of the American College of Gastroenterology: Prevention and management of gastroesophageal varices and variceal hemorrhage in cirrhosis. Hepatology 46: 922-938, 2007.

67. Samonakis DN, Triantos CK, Thalheimer U, Patch DW and Burroughs AK: Management of portal hypertension. Postgrad Med J 80: 634-641, 2004.

68. D'Amico G: The role of vasoactive drugs in the treatment of oesophageal varices. Expert Opin Pharmacother 5: 349-360, 2004.

69. Rosado B and Kamath PS: Transjugular intrahepatic portosystemic shunts: An update. Liver Transpl 9: 207-217, 2003.

70. Bosch J: The sixth Carlos E. Rubio memorial lecture. Prevention and treatment of variceal hemorrhage. P R Health Sci J 19: 57-67, 2000.

71. Patch D and Burroughs AK: Pharmacological treatment of portal hypertension. Prog Liver Dis 13: 269-292, 1995. 
72. D'Amico G, Pagliaro L and Bosch J: The treatment of portal hypertension: A meta-analytic review. Hepatology 22: 332-354, 1995.

73. Forns $X$, Ginès A, Ginès $P$ and Arroyo V: Management of ascites and renal failure in cirrhosis. Semin Liver Dis 14: 82-96, 1994

74. Iwakiri Y: Pathophysiology of portal hypertension. Clin Liver Dis 18: 281-291, 2014.

75. Ohnishi K, Nakayama T, Saito M, Hatano H, Tsukamoto T, Terabayashi H, Sugita S, Wada K, Nomura F, Koen H, et al: Effects of propranolol on portal haemodynamics in patients with chronic liver disease. Am J Gastroenterol 80: 132-135, 1985.

76. Mastai R, Bosch J, Navasa M, Kravetz D, Bruix J, Viola C and Rodés J: Effects of alpha-adrenergic stimulation and beta-adrenergic blockade on azygos blood flow and splanchnic haemodynamics in patients with cirrhosis. J Hepatol 4: 71-79, 1987.
77. Yoshiji H, Kuriyama S, Yoshii J, Ikenaka Y, Noguchi R, Nakatani T, Tsujinoue $\mathrm{H}$ and Fukui H: Angiotensin-II type 1 receptor interaction is a major regulator for liver fibrosis development in rats. Hepatology 34: 745-750, 2001.

78. Schepke M, Werner E, Biecker E, Schiedermaier P, Heller J, Neef M, Stoffel-Wagner B, Hofer U, Caselmann WH and Sauerbruch T: Haemodynamic effects of the angiotensin II receptor antagonist irbesartan in patients with cirrhosis and portal hypertension. Gastroenterology 121: 389-395, 2001. 